IIUM Journal of Educational Studies, 1:1 (2013), 1-12

Copyright (C IIUM Press

\title{
Islamization of Human Knowledge in Theory and Practice: Achievements, Challenges and Prospects in the IIUM context
}

\author{
Rosnani Hashim \& Ssekamanya Siraje Abdallah \\ Institute of Education, International Islamic University Malaysia (IIUM) \\ rosnani@iium.edu.my
}

\begin{abstract}
The International Islamic University Malaysia (IIUM) aims to become a leading international centre of educational excellence which seeks to restore the dynamic and progressive role of the Muslim Ummah in all branches of knowledge and intellectual discourse.Its mission has been crystallized during the period of Professor Mohd Kamal Hassan, its third Rector, as Islamization, Integration, Internationalization and Comprehensive Excellence or commonly known as Triple ICE. This paper deals with the achievements, challenges and prospects in the IIUM context of one of these four missions, namely, Islamization.
\end{abstract}

\section{Introduction}

Islamization is usually defined as a process to Islamize in term of faith, belief or worldview and thus it is applied to human beings (For the different conceptions of Islamization, see Abu Sulayman, 1989a, 1989b and 1994; Al-Alwani, 1995; Al-Attas, 1978; Bugaje, 1996; alFaruqi, 1982; Fazlur Rahman, 1988; Haneef, 2005; Rosnani \& Imran, 2000, Sardar, 1989; Ssekamanya et al., 2007 and 2011; Wan Mohd Nor, 1997 and 1998; and Yasien Mohamed, 1993 and 1994). In this sense it is similar to the calling to Islam or da'wah. However in the context of our discussion, Islamization is further extended to refer to the process of education, therefore including its philosophy, its curriculum which encompasses objectives, knowledge, methods and assessment (Rosnani, 2011). Islamization or da'wah, is a process that began with the mission of the Prophet Muhammad s.a.w. and his success is well documented in history.We at IIUM are a small part of that evidence. Philosophically, education in the Islamic tradition cannot be separated from the inculcation of faith and the realization of one's 'ubudiyyah (servanthood) and vicegerency (Husain \& Ashraf, 1979; alAttas, 1980). Thus, it was a rare occasion for a scholar to speak of the term Islamization of education or curriculum in the early period of Islamic civilization.

\section{Conception of Islamization of Human Knowledge (IOHK) in IIUM}

There are different conceptions of Islamization at IIUM and they have co-existed. Some scholars subscribed to the approach of S.M.N. al-Attas (al-Attas, 1978 and 1980 and Wan Mohd Nor, 1997 and 1998) which focused on desecularization or de-westernization of the Muslims from the secular worldview and in its place substituting it with the Islamic Worldview. This secularization, especially of education has caused the loss of adab or discipline of mind, spirit and body which led to confusion among Muslims especially that related to the hierarchy of knowledge and thus, the position of its possessors. That knowledge has lost its sacredness means that we need to regain it through IOK. Thus, it is argued that with the proper inculcation of the Islamic world view, the confusion will be overcome and the role of knowledge and education in restoring adab and faith in God will be restored (al-Attas, 1978 and 1980). Al-Attas' approach draws upon the rich tradition of Muslim scholarship, in particular the works of al-Ghazali, other philosophers, theologians, mystics and jurists. This approach was mainly used and propagated at the International Institute of Islamic Thought and Civilization (ISTAC) from its inception in 1989 (Wan Mohd 
Nor, 1998). A number of scholars in education, psychology and economics have adopted this approach.

The most widespread approach that was adopted at IIUM during its formative years since the second rector was that espoused by al-Faruqi (1982), Abusulayman (1989a, 1989b, and 1994), al-Alwani (1995) and the International Institute Islamic Thought (IIIT) based in Virginia, United States of America. This approach has been revised due to certain criticisms. Dr. Abdulhamid Abusulayman was instrumental in propagating this approach during his tenure as the Rector of IIUM (1988-1998). His emphasis was on the practical aspects of Islamization, i.e. how to make the lecturers involved and committed, rather than formulating a neat theoretical framework. Focusing on seeking the foundations of sciences in the Qur'an and the sunnah, this approach to Islamization was mainly critical of traditional Muslim scholarship, in particular the mystics. Consequently, it could not benefit from the works of the early Muslim philosophers, theologians and definitely not the Sufis. During this period there were important attempts toward Islamization in the humanities and social sciences with the IIUM organizing seminars, workshops and conferences that attracted the best Muslim scholars to participate. There were also practical attempts to Islamize the human sciences through workshops that brought together the Islamic Revealed Knowledge and the Human Sciences scholars within the Kulliyyah (Faculty) of Islamic Revealed Knowledge and the Human Science (KIRKHS) to discuss the possibility of coming up with an anthology. The fact that these two disciplines were housed under one roof, which is unlike the curriculum structure of other local universities such as Universiti Kebangsaan Malaysia (UKM) and Universiti Malaya (UM), is a reflection of this philosophy. These are all evidence of the IIIT's approach as delineated by al-Faruqi (1982) in his work Islamization of Knowledge: Workplan. However, the concrete output in terms of textbooks is dismal (Ssekamanya et al. 2007 and 2011).

The conception of IOK experienced a reconceptualization when another nomenclature (islamicization) was introduced for islamization, and popularized by Prof Kamal Hassan, the rector after Abusulayman. The nomenclature change signifies a shift in idea whereby the focus of Islamicization "should be on producing Muslim professionals who live in accordance with the aqidah(faith), shari'ah(law) and al-akhlaq al-karimah(good character). Knowledge is only one part of this process. Our emphasis should be on helping young Muslims to acquire useful knowledge which leads to moral action and good behaviour (husnulkhuluq)" (Ssekamanya et al., 2007). These differences in concepts and name of Islamization have led to differences in its implementation at IIUM.

\section{Phases of IOHK development in IIUM}

The IOK has been conceived as a mission of IIUM at the time of its foundation. However, this mission has been presented in different ways at different times depending on its leadership. Four phases can be discerned: (i) During the leadership of Prof M. A. Rauf (1983-88) who worked very closely with Prof Kamal Hassan; (ii) during the leadership of Dr. Abusulayman (1988-1998), (iii) during the leadership of Prof Kamal Hassan (19992005); and (iv) during the leadership of Prof Syed Arabi Idid (2005-2011). Although the top leadership has changed four times since then, this phase of Islamization seems to continue.

According to Ssekamanya et al. (2007 and 2011), there is a lot of similarity between the first and third phases. In the original concept of IIUM, the mission of Islamization was only implied and not openly stated. "The original purpose, according to Prof Muhammad Kamal Hassan, was to produce competent Muslim professionals who are excellent in their fields and at the same time having a good Muslim character... The core of Islamization efforts at IIUM was the establishment of the Centre for Fundamental Knowledge which served as a service centre for the other faculties. It was responsible for imparting knowledge 
of languages and the various disciplines of IRK as well as for organizing character development programs" (in an interview in 2007). There was no regimented movement for Islamization during the first phase (1983-1988) but lecturers worked hard to infuse Islamic values and perspectives in their courses. Most of them attempted to provide a comparison between Western and Islamic views too and this had motivated students to continue pursuing an integrative approach after graduation.

During the second phase, the leadership felt that IIUM was a good place to implement the idea of Islamization that has been germinated by the IIIT in the USA. The focus was not on students and their characters but rather on the disciplines, in particular the humanities and social sciences. This was an active period of disseminating the concept of Islamization of knowledge till it had become a political slogan. All academic staff was expected to comply with it whether they understood it or not. The capacity to contribute to Islamization became a criterion for recruitment or promotion decisions. The university senate gave serious weightage on the objective of Islamization in evaluating course outlines but less on producing Islamized textbooks and instructional materials (see, for instance, Ragab, 1993, 1997 and 1999).

In the third phase, there was a continuation of many of the structures and systems of Islamization put in place during the second phase. But in the absence of IIIT and its political machinery and financial resources, Islamization became less of a political process and took on an academic nature. The system of coercion seems to give way to a soft-touch approach. Because of Prof Kamal Hassan's approach that IOK can be discussed and debated and not imposed on anyone, this has given freedom to scholars in IIUM to follow any approach that suits them. Finally, in the fourth phase, there seems to be more focus on achieving the status of a research university with IOK taking a backseat, although the leadership pledged IIUM's commitment to Islamization as the core of its vision and mission. Those scholars who are familiar with the dynamism of the 1990s were wondering whether the leadership had somehow abandoned IOK and this led some to a state of confusion.

\section{Evaluation of IOK in IIUM - Achievements}

Has IIUM succeeded in this mission of reforms? Has it succeeded in exporting the ideas of integration and Islamization to other Muslim countries through its students or the activities of its academic staff? Although within the institution many of its people are still not satisfied with its performance, IIUM has kept to the vision and mission of its establishment. It has managed to offer both the acquired and traditional Islamic sciences and graduate many successful professionals.

Studies that have attempted to examine the achievements of Islamization at IIUM (e.g., Sardar, 1989, Safi, 1993; Nik Ahmad Hisham et al., 2003; Haneef, 2005; Ssekamanya et al. 2007 and 2011; and Rosnani, 2011) concur that greatest achievement ${ }^{1}$ of IOK in IIUM is the recognition given to Islamization as one of the core vision and mission of the institution. The commitment of the university top management to this mission has been consistent - in staff promotion and recruitment, in the university senate deliberation in approving course outlines, in its staff professional development programmes as well as students' development programmes. This mission is impressed upon every academic and administrative staff and students. Together with Islamization, integration of the revealed

\footnotetext{
${ }^{1}$ The discussion on achievements have been based on Ssekamanya, S. A, M Sahari, N., Nik A. Hisham, I. \& Abdullah, S. A. (2007), Islamization of contemporary knowledge: analyzing the experiences of selected scholars at the IIUM. Unpublished research report
} 
knowledge and acquired knowledge and integration of Islamic Worldview, ethics and values in all knowledge and university activities have become another core vision and mission. This recognition is not only limited within the IIUM community but is now recognized by the Ministry of Higher Education (MOHE) Malaysia as the niche of the university and the recent recognition of the Global Premier Islamic University attests to this fact.

A second achievement is the ability of IIUM to attract quality Muslim scholars from Malaysia and abroad. The intellectual discourses between those scholars in the humanities and social science and those in the Islamic Revealed Knowledge have provided rare avenues for exchange of contemporary theories and Qur'anic sciences relevant to their fields.

The third achievement is in the curriculum of IIUM where IOK has been made the primary features in all programme learning outcomes, course contents and evaluation methods. IOK is now recognized by the Malaysian government and employers as the niche of the IIUM. The teaching method most commonly applied is firstly, comparative with some courses mainly dealing with Western perspectives, secondly, integrative where both the Islamic and western perspectives are taught side by side, and thirdly, for the technical and professional courses not having philosophical presuppositions, the focus is on fostering Islamic character among students. The Department of General Studies has been established to service students on the university core Islamic courses namely the Islamic worldview and Islamic ethics. Several co-curricular progarmmes have also been designed to foster Islamic characters and spirituality. Another feature of the IIUM curriculum is the double degree which if taken with one from IRK and another in the acquired aciences, is capable of producing the 'hybrid' Muslim scholars who will be able to enhance the mission of IOK to a higher degree in the future.

The fourth achievement is in the students that is the graduates of IIUM. The university seems to attract students who are interested in Islamization and Integration. Many of the IIUM graduates have made a major impact in their workplaces in different countries in the world. Those who have earned their PhD from the University have a greater impact and many are now employed as academicians in their own countries. Even those who may not appear to have much commitment to Islam are beginning to exert a positive influence at least within their family circle, for example those from the Balkan states and Central Asia in which Islam has been separated from the people's lives for a long time.

Rosnani (2011) found from her study of 159 graduates and alumni of IIUM of which 53 were Malaysians and 106 were international students, that they have strongly been influenced by this mission of the university. In fact $71 \%$ of the 159 respondents surveyed chose to study in IIUM for its Islamicity and mission of integration. With that intention, it is not surprising that in the same survey that employed a five point Likert scale of agreement, $52 \%$ agreed and 28\% strongly agreed that IIUM has been important in giving a proper understanding of the Islamic Worldview, 52\% agreed and 28\% strongly agreed that IIUM has been important in giving an integrated education of both the Shari'ah and Aqli sciences; 85\% felt that their understanding of the unity of knowledge and its relation to faith and life was better after studying in IIUM. In fact $30 \%$ felt very much so. A majority of the respondents (72\%) surveyed felt that their life as a Muslim has been transformed to the better as a result of studying in IIUM. Thus in a sense the education offered in IIUM has been effective. We would expect changes to gradually take place in future once these graduates become the lecturers of institutions of higher learning or social activists in their own countries. A good example would be Indonesia, Maldives, Bangladesh, Kerala (India) and Malaysia where these ideas have already permeated into society.

Fifth, a lot of research and publications on the conceptualization of IOK and its methodologies has been generated in IIUM. In some areas, IIUM scholars have developed expertise in producing Islamic solutions for current problems faced by Muslim societies such 
as in Islamic economics, finance, banking and insurance, and Islamic education. IIUM scholars are now recognized worldwide and are sought as experts and consultants in other areas where they have made breakthrough innovations in the legal field, especially in the areas of shari'ah, family, criminal and commercial law. In education, their expertise are sought for curriculum and instructional material development especially for Islamic schools and fairly recently in the pedagogy of Islamic philosophical inquiry. The outcome of research by IIUM scholars and their graduate students are research papers and books which will further champion the cause of IOK (Ssekamanya, S. A., M. Sahari, N., Nik A. Hisham, I. \& Abdullah, A. S., 2007)

Finally, IIUM has succeeded in fostering Islamic brotherhood and respect for cultural diversity. One of the KPIs related to international students and campus life is the ability of the institution to provide a life where the international ambience is welcomed. Having an international students' office is one of the means, but the other facilities like the cafetaria, classroom, residential halls and co-curricular activities should encourage and foster a good life. The cultural diversity of Muslims despite sharing the same faith is a fact and what more with people of other faiths or cultures. Thus it is vital for IIUM to foster brotherhood, mutual respect and the ethics of differences among its students. A survey by Rosnani (2011) shows that this aim has been achieved. Almost all students (96\%) began to be aware of the cultural diversity that Muslims from various countries possess after studying in IIUM. Most of them (94\%) began to understand how other Muslims who come from different cultures think and act. Almost all (90\%) felt that being in IIUM has helped them understand the need for ethics of differences and mutual respect. Their brotherhood also became stronger as evidence by inter cultural marriages that took place in campus. The graduates $(44 \%)$ frequently and most often communicate or keep in touch with their international friends and this should be easy with the availability of the email, facebook, twitter etc.

\section{Challenges/ Where do we go from here?}

The scholars' who were interviewed in the study conducted by Siraje et al. (2007) felt that there are still many IIUM lecturers who are unclear about the Islamization and Integration agenda. I do agree with this observation, but actually, IIUM has succeeded in raising the awareness of these agenda among its academic and administrative staff, although this is only the first stage of the taxonomy of educational objective for the affective domain. Our staff have also responded to this phenomenon either by agreeing or disagreeing or being simply indifferent and that is the second stage. I think many are still blocked at the third stage of valuing which ranges from simple acceptance to the more complex state of commitment. Valuing is based on the internalization of a set of specified values, while clues to these values are expressed in the learner's overt behavior and are often identifiable. Thus, we are not able to proceed to the fourth stage of organization that is organizes values into priorities by contrasting different values, resolving conflicts between them, and creating a unique value system. The emphasis is on comparing, relating, and synthesizing values. We are also unable to proceed to the fifth and final stage of Internalizing values (characterization), that is having a value system that controls behaviour. The behaviour is pervasive, consistent, predictable, and most importantly, characteristic of the lecturer. Due to this many of the firm believers who have internalized the values of Islamization of Education and knowled ge felt the newer generation as not committed as they are (see also Nik Ahmad Hisham et al., 2003).

Secondly, the scholars in S. Siraje et al. (2007)'s study observed that a majority of IIUM scholars are not proficient in Islamic traditional sciences and the Arabic Language, both of which are crucial for effective IOK. But the real problem they believed is in the lack of commitment to the mission by many of them. The "cross-fertilization" of ideas in KIRKHS did not happen and the Diploma in Islamic Science offered by KIRKHS to assist 
young lecturers with the knowledge and tools to enable them to contribute to IOK is on the decline. It was found that most of the Islamic heritage program seems to only focus on the basics of theology and fiqh and rarely a deep treatment of the historical and philosophical dimensions. Even if the young lecturers studied in the West, their knowledge of the discipline does not run deep because not many understand its historical and philosophical underpinnings. This results in many academic staff who are committed to IOK ending with half-baked Islamization, i.e. with just some verses of the Holy Qur'an. Another issue related to commitment and the different existing versions of IOK is the confusion among some academicians. They have good intention but without knowing fully well what they are supposed to do. For this group of scholars, it would be helpful if there were Islamized materials for them to use.

Thirdly, the absence of Islamized materials and textbooks is a major hurdle to the successful implementation of the IOK. At the end, more than 90 percent of the curriculum is based on Western, especially American theories and books. Sometimes verses of the Qur'an and Islamic references are sprinkled in the course outlines just to satisfy the Senate.

Fourthly, local economic conditions such as employability and the job market will deter some students from opting for the double degree with IRK as one of the majors. If this is abandoned, then the integration that IIUM is aiming at will be sidetracked. This is a big challenge to the mission of IOK. Another local factor is the policy of the MOHE to implement the 60:40 ratio for science and technology to arts in the interest of the national economy. This means the best students will opt for science and technology (S\&T) and the remainder for social science and humanities i.e. the cream of society will opt for S\&T leaving the poor remainder to do social sciences including IRK. Another challenge is the current system of quality assurance and the practice of ranking universities globally and locally. To compete with the other universities locally or globally means to do almost the same thing that the others are doing based on the set criteria by the ranking agencies. This might mean the neglect of IOK in the long run.

Finally, we noticed that the commitment to this mission of Islamization and Integration and the other missions of IIUM as well has its ebb and flow, and it depends very much on the commitment of the Top Management of the university itself. If the highest management body of the university is committed to it by its action, then the Kulliyyah/ Centres/ Divisions/ Institutes will catch it and begin to change. Similarly, at the Kulliyyah level, it depends very much on the Dean/ Director. The newly created Centre for Islamization (Centris) reflects the commitment of the present Rector to the Islamization agenda.

\section{Suggestions for improvement}

First, there seems to be a lack of commitment from among scholars. There are many reasons for the differences in the staffs' response to Islamization. Those who disagree or are indifferent probably have not been impressed on its necessity or its viability. They have probably seen the other sides of the arguments and are more convinced by it or they have not seen anything concrete by its proponents in the IIUM itself. For the sake of clearing the confusion it is necessary to help IIUM scholars to understand what IOK is and the various approaches to achieve it. We need to answer this fundamental question: Have we attained the integrated mind/scholar/researcher, and the generation of Islamic knowledge?

If not, then we should rethink our conceptualization and our strategies. I think we should consider IOK as having two phases:

Phase 1: the birth of the scholars

Phase 2:Islamization of the knowled ge 
IIUM Journal of Educational Studies, 1:1 (2013), 1-12

Copyright (C IIUM Press

Al-Faruqi and al-Attas did not separate the two processes in their respective conception. Hence, I believe this has led to some confusion in the formulation of their goals (good man, Islamic knowledge, individual and ummatic agenda). How can we succeed in phase 2 (Fig 2) without success in phase 1 (Fig 1)?

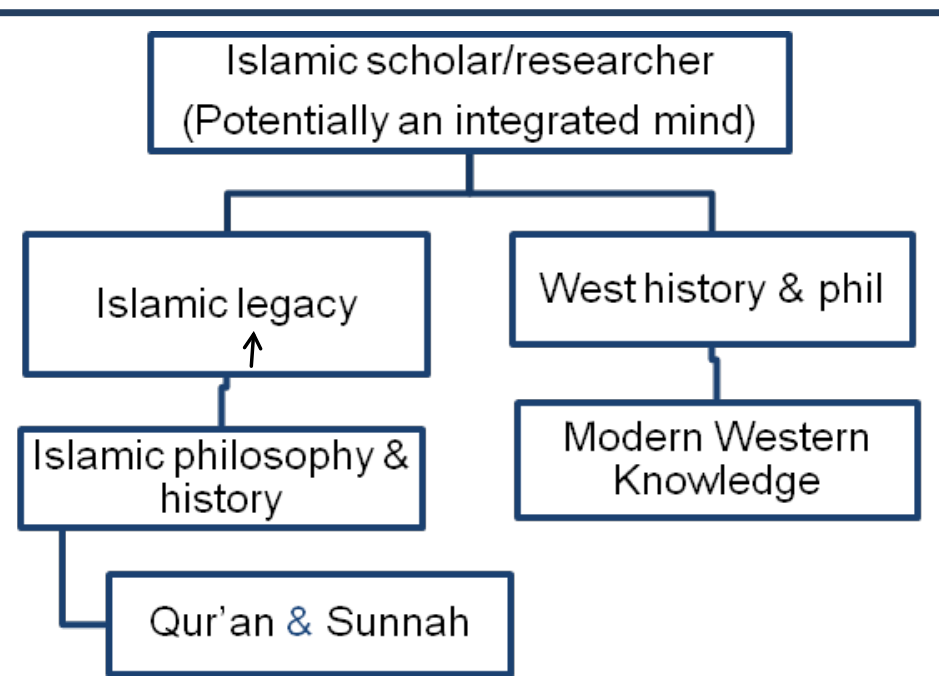

Figure 1: Phase 1 - Birth of the scholar

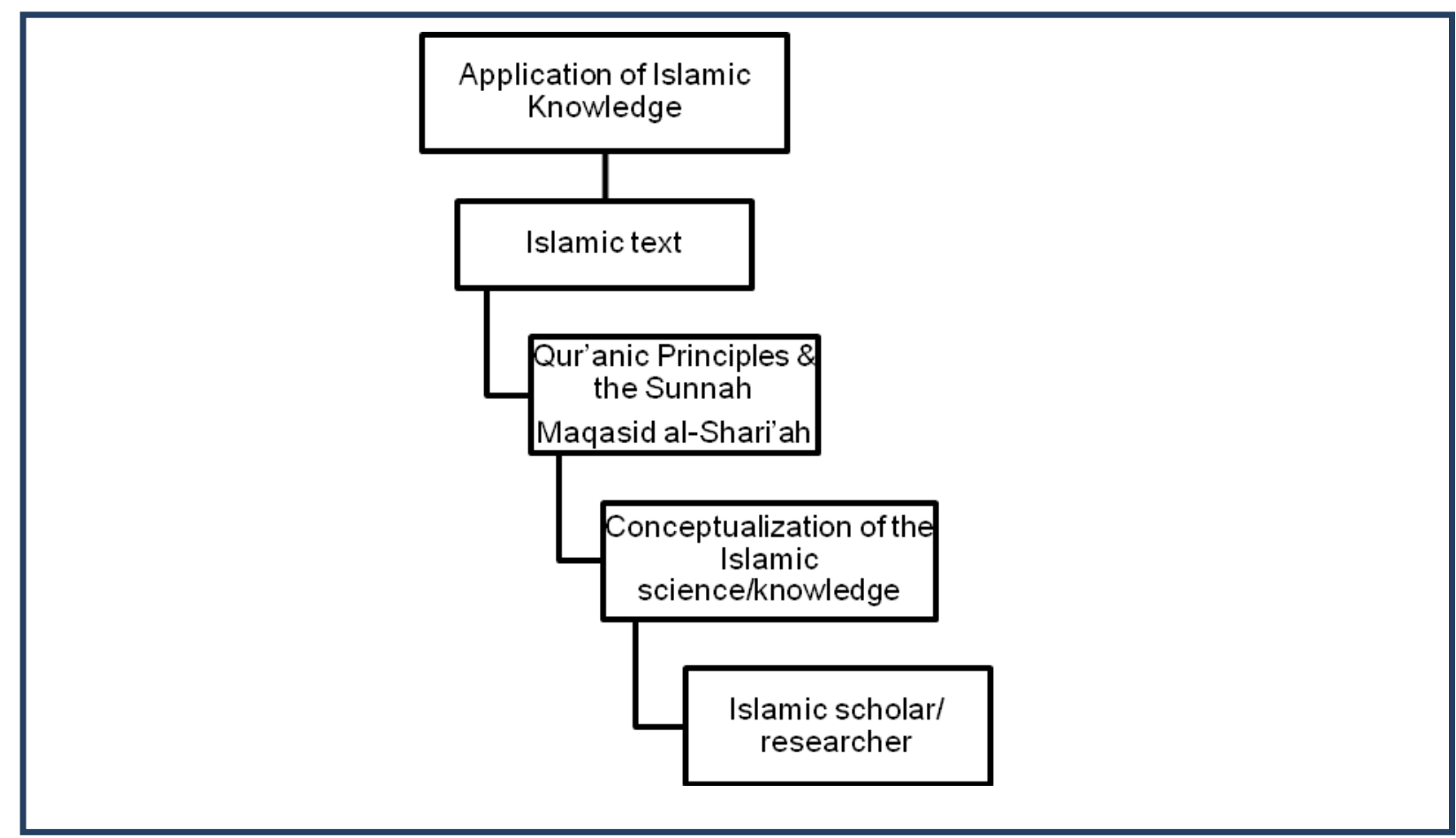

Figure 2: Phase 2 - Islamized knowledge \& products 
During the late 1970 s, phase 1 was achieved through non-formal education - would be scholars had an interest and a sense of responsibility in it. Then ISTAC fulfills the role of phase 1 but it was elitist then. What about the professionals such as medical doctors, engineers, lawyers, etc?.Is it adequate with a few IRK courses such as Islamic ethics and Islamic Worldview? These do not ground our students to the history and philosophy of knowledge development.

Therefore I suggest that IIUM offer survey courses on

- Islamic Philosophy and History, and

- Western Philosophy and History;

- Introductory reading of the Qur'an and hadith as reference

- Selected classic works of great Muslim scholars: The Imam of the school of fiqh Ash-Shafi'e, Ibn Hanbal, Abu Hanifah, Malik; the great philosophers - al-Farabi, IbnSina, Ibn Tufayl, Ibn Rushd, the theologians Al-Ghazali, al-Mawardi, etc. in which students can elect to take one work of interest to study.

- $\quad$ Produce anthologies as suggested by Al-Faruqi.

Thus we suggest the following strategy with respect to our curriculum:

a. Lay down IOK in the proper perspective of knowled ge or epistemology.

b. Examine the classification of knowledge of scholars of the past (eg al-Farabi, Ikhwan al-Safa and al-Ghazali), and the present to provide for the philosophical foundation of our curricula. For example, would the classification of Ikhwan al-Safa be more useful today?

c. Produce works on some disciplines that require a complete overhaul (e.g. social and human sciences). Rectify its historical, philosophical and sociological foundations.

d. Provide supplementary works and philosophical foundations for some disciplines that only require a re-alignment eg. natural and applied sciences which needs an overhaul especially tho se based upon Darwinian theory of evolution and survival of the fittest.

e. The auxiliary knowledge or instrumental knowledge such as language and ICT. These are tools. The values depend very much on the user like the use of the knife.

Should we have a relook at the ikhwan al-safa classification of knowledge which provides a classification based on the human mind, spirit and body:

1. The Primary (propaedeutic) sciences (riyadiyah),

2. Religious sciences (Al-shari `at al-wad `iyah) and

3. Philosophical sciences (al-falsafiyat al-haqiqiyah)

Second, the understanding of Islamization as a comprehensive approach ought to be translated to also include Islamization of human personality (both scholars and students). Most of these attempts so far, focused on IOK and not the human persons. In this regard it is suggested that ibadah camps with its established speakers and facilitators to enlighten students and lecturers be revived and community or social services be taken up.

Third, it was also found that one of the greatest barriers against IOK is the lack of textbooks with the Islamic perspective or worldview in various disciplines. Current efforts at IOK assume that all scholars are capable of providing the Islamic perspectives on their disciplines, which is not the case. The availability of these materials will ease the work of many lecturers. IIUM needs to strategize on textbook writing. The University must commit itself by freeing a few of its acknowledged, competent scholars in this area to give workshops and to review course outlines of selected priority courses, followed by writing the textbook. There is no short cut to these and the university has lost so many years because it has not focused on this matter. 
IIUM Journal of Educational Studies, 1:1 (2013), 1-12

Copyright (C) IIUM Press

\section{Conclusion}

To conclude, IIUM should not be trapped into the tendency to formulate the Islamization issue at a very ethereal level of abstraction. It should pay attention on the particular, specific and concrete as well. It should also aim to make a difference in the classroom, to the learning experience and hence how students relate to what they learn. Islam, as you know, has been de-intellectualized and hence teaching of Islam (Islamic studies) has suffered the same fate. We ought to make learning about Islam an intellectual enterprise again and therefore interesting and meaningful. The difference between who is a Muslim and what it is to be Muslim as informative and transformative respectively is the key to what is involved. In this regard too, the university should translate the meaning of the objective of 'abd and khalifah into something that is action oriented. In this context the relationship of the 'abd to Allah is one of taqwa. But one cannot have this taqwa if one is not society oriented in the sense that one cares for social justice and all the Islamic values. This is the 'amr bi'l-ma'aruf wanahyu 'anilmunkar' (enjoin the good and forbid the evil) consciousness. In this context the Hikmah Pedagogy of philosophical inquiry should be employed by IIUM academic staff to ensure that learning has a higher purpose and should help our students reflect on how they can contribute to society as a service to Allah and be able to think critically of the events around them, and think of actions against any form of injustices.

Wallahu 'alam.

\section{References}

Abu Sulayman, A. H. (1989). Islamization of Knowledge. Riyadh: International Islamic Publishing House and IIIT.

Abu Sulayman, A. H. (1994). Islamization: Reforming Contemporary Knowledge. Herndon, VA: IIIT.

Abu Sulayman, A. H. (1989). Islamization of Knowledge: General Principles and Workplan. Herndon, VA: IIIT.

Al-Alwani, T. J. (1995). Islamization of Knowledge: Yesterday and Today. AJISS, 12 (1): 81-101.

Al-Attas, S. M. N. (1978). Islam and Secularism. Kuala Lumpur: ABIM.

Al-Attas, S. M. N. (1980). The Concept of Education in Islam: A Framework of an Islamic Philosophy of Education. Kuala Lumpur: ABIM.

Bugaje, U. (1996). Contemporary Muslim Response to the Challenge of Knowledge: Separating the Grain from the Chaff. Encounters, Journal of Cultural Perspectives. 2(1).

Al-Faruqi, I. R. (1982). Islamization of Knowledge: The Problem, Principle, and Workplan. Hemdon, VA: IIIT.

Fazlur Rahman. (1988). "Islamization of Knowledge: A Response." AJISS , 5(1): 3-11.

Haneef, M. A. (2005). A Critical Survey of Islamization of knowledge. Kuala Lumpur: IIUM. 
IIUM Journal of Educational Studies, 1:1 (2013), 1-12

Copyright (C IIUM Press

Husain, S. S. \& Ashraf, S. A. (eds.). (1979). Crisis in Muslim Education. Jeddah: King Abdulaziz University.

Kazemi, Y. (1998). "Reclaiming the Tradition: An Essay on the Condition of the Possibility of Islamic Knowledge". AJISS, vol. 15(2): 97-108.

Nasr, S. H. (1988). Islam and the Problem of Modern Science. MAAS Journal of Islamic Science, 4 (1): 59-74.

Nik Ahmad Hisham, I., Nik Suryani, N. A. R., Mohd Sahari, N., \& Ahmad Marzuki, H. Z. (2003). Integration and Intemalization in the Inter-Group Relations in Institutions of Tertiary Education: A Case Study of the International Islamic University Malaysia. Muslim Education Quarterly, vol. 20 (1\&2): 52-66.

Ragab, I. A. (1993). "The Islamic Perspective on Theory Building in the Social Sciences." AJISS, $10(1): 1-22$.

Ragab, I. A. (1997). Creative Engagement in Modern Social Science Scholarship: A Significant Component of the Islamization of Knowledge Effort. Intellectual Discourse, 5 (1): 35-49.

Ragab, I. A. (1999). On the Methodology of Islamizing Social Science. Intellectual Discourse., 7 (1): 27-52.

Rosnani, H. \& Imran, R. (2000). Islamization of Knowledge: A Comparative Analysis of the Conception of Al-Attas and al-Faruqi. Intellectual Discourse, 8 (1): 19-44.

Rosnani, Hashim (2011) Internationalisation of Contemporary Islamic Higher Education and Ummatic Development: A Case Study of the International Islamic University Malaysia (IIUM). Paper presented at the International Seminar on Reforms in Islamic Higher Education in Meeting Contemporary Challenges, Nagoya University $30^{\text {th }}-31^{\text {st }}$ July 2011.

Safi, L. (1993). "The Quest for an Islamic Methodology: The Islamization of Knowledge Project in its Second Decade." AJISS , 10 (1): 23-48.

Sardar, Z. (1989). "Islamization of Knowledge: A State of the Art Report." In Ziauddin Sardar (ed.), An Early Crescent: The Future of Knowledge and the Environment in Islam. London:Mansell

Ssekamanya, S. A., M Sahari, N., Nik A. Hisham, M.S., Ismail, N.A.H. \& Abdullah, A. S. (2007) "Islamization of contemporary knowledge: analyzing the experiences of selected scholars at the IIUM." Unpublished research report.

Ssekamanya, S. A., Suhailah H. \& Nik Ahmad H. I. (2011)."The experience of Islamization of Knowledge at the International Islamic University Malaysia: successes and challenges." In New Intellectual Horizons in Education (ed. Yedullah Kazmi). Gombak: IIUM Press, pp. 91-110.

Wan Mohd Nor, W. D. (1997). "Islamization of Contemporary Knowledge: A Brief Comparison between al-Attas and Fazlur Rahman." Al-Shajarah, 2(1):1-19.

Wan Mohd Nor, W. D. (1998). The Educational Philosophy and Practice of Syed Muhammad Naquib al-Attas: An Exposition of the Original Concept of Islamization. Kuala Lumpur: ISTAC. 
IIUM Journal of Educational Studies, 1:1 (2013), 1-12

Copyright (C) IIUM Press

Yasien Mohamed. (1993). "Islamization: A Revivalist Response to Modernity." Muslim Education Quarterly, 10 (2): 2-23.

Yasien Mohamed. (1994). "Islamization of Knowledge: A Critique." AJISS, 11 (2): 282-293.

Yasien Mohamed. (1993). "Islamization of Knowledge: A Comparative Analysis of Faruqi and Rahman." The Muslim Education Quarterly, 2 (1): 27-40. 